\title{
Rituximab therapy in a patient with low grade B-cell lymphoproliferative disease and concomitant acquired angioedema
}

This article was published in the following Dove Press journal:

Journal of Asthma and Allergy

2 December 2014

Number of times this article has been viewed

\section{Ravdeep Kaur \\ Aerik Anthony Williams \\ Catherine Baker Swift Jason W Caldwell}

Wake Forest University School of Medicine, Wake Forest University, Winston-Salem, NC, USA
Correspondence: Aerik Anthony Williams

Wake Forest University Medical Center, 23II Lewisville Clemmons Rd, Clemmons, NC 27012, USA

$\mathrm{Tel}+\mathrm{I} 6145064374$

Fax +I 3367164734

Email aerikwilliams@hotmail.com
Abstract: Acquired angioedema is often associated with significant morbidity. An underlying lymphatic malignancy, autoimmune disorder, adenocarcinoma, or other malignancy may be present. Screening for these disorders should occur in all patients with acquired angioedema as treatment may result in resolution of angioedema.

Keywords: complement, C1-INH deficiency, ecallantide, hemopathy

\section{Introduction}

Acquired deficiency of the inhibitor of the first component of human complement $(\mathrm{C} 1-\mathrm{INH})$ is an extraordinarily rare cause of intermittent episodes of angioedema, with approximately 100 cases reported in published literature. ${ }^{1}$ Underlying low grade lymphoid hemopathies, in which immediate chemotherapy is typically unwarranted, may be associated with acquired $\mathrm{C} 1-\mathrm{INH}$ deficiency. In such patients, treatment with rituximab (Genentech, Inc., San Francisco, CA, USA) can ameliorate symptoms of angioedema. ${ }^{2,3}$

\section{Case presentation}

A 51-year-old male with a past medical history of chronic obstructive pulmonary disease and depression described a 2-year history of intermittent edema of the hands, feet, genitals, and tongue occurring approximately once per month. He had experienced two episodes of laryngeal edema requiring intubation. He denied any associated urticaria, pruritus, or flushing. He had been managed acutely for these symptoms with epinephrine injection, corticosteroids, and antihistamines with no improvement. His active medications were albuterol and duloxetine. At the time of presentation he was a current smoker with a 15-pack-year history. He was seen in consult in the critical care unit of Wake Forest Baptist Medical Center, Winston-Salem, NC, USA after an episode of laryngeal edema requiring intubation. An undetectable $\mathrm{C} 4$ of $<5 \mathrm{mg} / \mathrm{dL}$ (reference range [ref] 15-70 mg/dL) prompted administration of $30 \mathrm{mg}$ of subcutaneous ecallantide (Dyax Corp, Burlington, MA, USA), which led to rapid resolution of swelling. Further complement assays were consistent with acquired C1-INH deficiency: C1-INH of $5 \mathrm{mg} / \mathrm{dL}$ (ref: $21-39 \mathrm{mg} / \mathrm{dL}$ ), a C1-INH function of $16 \%$ (ref: $>68 \%$ ), and undetectable C1q of $<3.6 \mathrm{mg} / \mathrm{dL}$ (ref: $5-8.6 \mathrm{mg} / \mathrm{dL}$ ).

Evaluation to ascertain an etiology of acquired angioedema led to the discovery of an increased total number and percentage of B-cells (1,240 cells/ $\mu \mathrm{L}$ [ref: $50-870$ cells $/ \mu \mathrm{L}$ ] and 34\% [ref: 5\%-17\%]). In addition, the percentage of T-lymphocytes was low $(62.9 \%$ 
[ref: 66\%-90\%]); however, the total T-lymphocyte count was normal $(2.39 \times 1,000$ cells $/ \mu \mathrm{L}$ [ref: $0.66-4.59 \times 1,000$ cells $/ \mu \mathrm{L}])$. Peripheral flow cytometry identified a B-cell population with excess kappa expression that was CD5/10 negative and CD19/20 positive, suggesting a monoclonal B-cell population.

Three months after hospitalization, the patient was evaluated by the oncology team at Wake Forest Baptist Medical Center. At this time, he was experiencing angioedema approximately twice per week. Bone marrow biopsy revealed atypical lymphoid aggregates with a monoclonal B-cell population. A positron emission tomography-computed tomography (PET-CT) demonstrated no hypermetabolic activity or evidence of lymphoma, but did reveal a spiculated $1 \mathrm{~cm}$ nodule in the right apical lung. The lung nodule prompted a wedge resection. Histopathology demonstrated dense fibrosis with chronic inflammation without evidence of malignancy, specifically adenocarcinoma. The lung nodule was an incidental finding, not believed to be associated with the monoclonal B-cell population nor acquired angioedema.

Though the "watch and wait approach" was considered for treatment of the patient's low grade B-cell lymphoproliferative disease, the frequency and severity of angioedema was concerning. Our preference was to treat his lymphoproliferative disease in order to prevent future angioedema, as opposed to acute management with ecallantide or prophylactic management with $\mathrm{C} 1$-esterase inhibitor concentrate indefinitely. Ecallantide is not a disease modifying drug; therefore, the decision was made to start rituximab $375 \mathrm{mg} / \mathrm{m}^{2}$ weekly for 4 weeks. Since his first dose of rituximab 9 months ago, he has had no further episodes of angioedema.

\section{Discussion}

Acquired C1-INH deficiency is characterized by consumption of C1-INH; however, the pathophysiologic mechanisms are not clearly defined. Type I acquired C1-INH deficiency describes patients with lymphoproliferation and excessive C1-INH consumption. ${ }^{4}$ Type II acquired C1-INH deficiency describes anti-C1-INH autoantibody production in the setting of monoclonal gammopathy of unknown significance (MGUS) or B-cell lymphoid hemopathy. ${ }^{2}$ Consumption of C1-INH leads to hyperactivation of the classical complement pathway and fibrinolytic system with resultant low plasma C4, low plasma C1q, normal plasma C3, and elevated bradykinin levels. ${ }^{5,6}$ Clinical manifestations include intermittent angioedema of the subcutaneous tissues in the absence of urticaria and pruritus, and appears to be largely mediated by bradykinin. Pharmacologic treatment options for acute attacks include $\mathrm{C} 1$-INH concentrate, kallikrein inhibitor concentrate, and $\mathrm{B} 2$ bradykinin receptor blockade agents.

Chemotherapy for MGUS or B-cell lymphoproliferative disease is not always indicated; however, patients with concomitant acquired CI-INH deficiency may benefit from such treatment. In a patient with acquired angioedema and B-cell lymphoma, Levi et al described cessation of symptoms after treatment with rituximab. ${ }^{3} \mathrm{~A}$ review by Branellec et al describes outcomes of rituximab therapy in seven patients with acquired CI-INH deficiency, five of which had an underlying B-cell lymphoproliferative disease or MGUS. ${ }^{2}$ Two of these five patients had no subsequent attacks after treatment.

Certainly the prevalence of acquired angioedema in the setting of low grade B-cell lymphoproliferative disease is low, with only a few case reports published in literature. Trials in which such patients are randomized to a rituximab group or alternative therapy group are impractical. Therefore, case reports are paramount so that practitioners can make management decisions based on a collective experience.

In the above patient with acquired $\mathrm{C} 1-\mathrm{INH}$ deficiency in the setting of low grade B-cell lymphoma, rituximab eradicated symptoms of life threatening angioedema. Therefore, rituximab warrants consideration for patients with recurrent angioedema in the setting of acquired C1-INH deficiency and low grade B-cell lymphoproliferative disease.

\section{Disclosure}

The authors report no conflicts of interest in this work.

\section{References}

1. Cicardi M, Zingale LC, Pappalardo E, Folcioni A, Agnostoni A. Autoantibodies and lymphoproliferative diseases in acquired C1-inhibitor deficiencies. Medicine (Baltimore). 2003;82(4):274-281.

2. Branellec A, Bouillet L, Javaud N, et al. Acquired C1-inhibitor deficiency: 7 patients treated with rituximab. J Clin Immunol. 2012;32(5):936-941.

3. Levi M, Hack CE, van Oers MH. Rituximab-induced elimination of acquired angioedema due to C1-inhibitor deficiency. Am J Med. 2006; 119(8):e3-e5.

4. Jackson J, Sim RB, Whaley K, Feighery C. Autoantibody facilitated cleavage of $\mathrm{C} 1$-inhibitor in autoimmune angioedema. $J$ Clin Invest. 1989;83(2):698-707.

5. Agostoni A, Cicardi M. Hereditary and acquired C1-inhibitor deficiency: biological and clinical characteristics in 235 patients. Medicine (Baltimore). 1992;71(4):206-215.

6. Shoemaker LR, Schurman SJ, Donaldson VH, Davis AE 3rd. Hereditary angioneurotic oedema: characterization of plasma kinin and vascular permeability-enhancing activities. Clin Exp Immunol. 1994;95(1):22-28. 
Journal of Asthma and Allergy

\section{Publish your work in this journal}

The Journal of Asthma and Allergy is an international, peer-reviewed open-access journal publishing original research, reports, editorials and commentaries on the following topics: Asthma; Pulmonary physiology; Asthma related clinical health; Clinical immunology and the immunological basis of disease; Pharmacological interventions and

new therapies. Issues of patient safety and quality of care will also be considered. The manuscript management system is completely online and includes a very quick and fair peer-review system, which is all easy to use. Visit http://www.dovepress.com/testimonials.php to read real quotes from published authors.

Submit your manuscript here: http://www.dovepress.com/journal-of-asthma-and-allergy-journal 